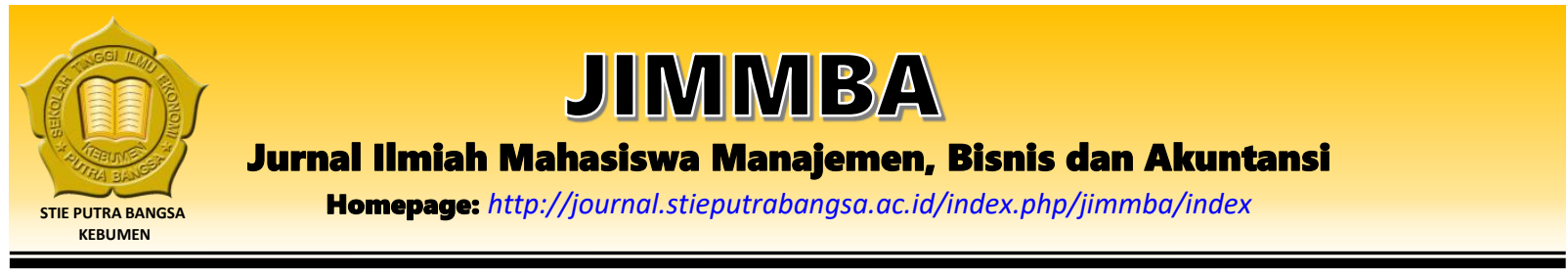

\title{
Pengaruh Perceived Usefulness, Perceived Ease of Use Terhadap Trust dan Intention to buy KAI Access Tickets Online pada Generasi Millennial di Kabupaten Kebumen
}

\author{
Riani Mujiasih', Gunarso Wiwoho² \\ 1Sekolah Tinggi Ilmu Ekonomi Putra Bangsa \\ 2Sekolah Tinggi Ilmu Ekonomi Putra Bangsa \\ Email: real.rianimujiasih@gmail.com
}

\section{ARTICLE INFO}

Article History:

Received: March 14th 2020

Accepted: March $16^{\text {th }} 2020$

Published: June 30th 2020

Keywords:

Perceived Usefulness,

Perceived Ease of Use,

Trust, Intention to buy,

Millennials

\begin{abstract}
This study aims to determine the effect of perceived usefulness and perceived ease of use on the intention to buy KAI Access tickets online through an trust as an intervening variable. The population in this study were millennials generation of Kereta Api Indonesia (KAI) users service in Kebumen Regency. This study sample was 100 respondent using the purposive sampling method. The method used in this study is a quantitative method. Data analysis using path analysis with SPSS 23 program. The results of this study indicate that perceived usefulness and perceived ease of use have a significant effect on trust. While perceived ease of use do not affect the intention to buy KAI Access tickets online, while the perceived usefulness and trust significantly influences the intention to buy KAI Access tickets online.
\end{abstract}

\section{Pendahuluan}

Di era globalisasi dengan kemajuan teknologi yang semakin berkembang, menimbulkan perilaku generasi millennials yang menuntut kehidupan praktis dan efisien. Dikutip dari kominfo.go.id generasi millennials atau generasi Y adalah mereka yang lahir pada tahun 1980 sampai 2000. Perilaku generasi millennials yang cenderung memanfaatkan teknologi dalam kehidupan sehari-hari, menimbulkan perusahaan jasa khususnya jasa transportasi kereta api indonesia menghadirkan aplikasi KAI Access sebagai media untuk mendapatkan tiket kereta api secara online. Berdasarkan observasi terhadap beberapa generasi millennials di Kabupaten Kebumen, 26 dari 30 responden menjawab menggunakan aplikasi KAI Access di dalam membeli tiket kereta api secara online. KAI Access adalah official mobile ticketing yang dikeluarkan PT Kereta Api Indonesia pada tahun 2014 dengan berbagai fitur yang dapat dimanfaatkan oleh pengunna kereta api. Dengan adanya strategi pemanfaatan teknologi KAI Access tersebut diperkirakan menimbulkan adanya peningkatan jumlah penumpang orang dalam setiap tahun. Berikut adalah tabel jumlah penumpang kereta api jenis penumpang orang tahun 2013-2018. 
Tabel 1. Pengguna kereta api penumpang tahun 2013-2018

\begin{tabular}{cc}
\hline Tahun & $\begin{array}{c}\text { Penumpang } \\
\text { (ribu orang) }\end{array}$ \\
\hline 2013 & 216 \\
2014 & 278 \\
2015 & 326 \\
2016 & 352 \\
2017 & 393 \\
2018 & 422 \\
\hline www.bps.go.id (2018)
\end{tabular}

Berdasarkan tabel Pengguna Kereta Api jenis penumpang orang tahun 2013-2018 selalu mengalami peningkatan yang cukup signifikan. Peningkatan jumlah penumpang tersebut menunjukkan adanya kepercayaan masyarakat kebumen terhadap jasa layanan kereta api indonesia. Berkaitan dengan kereta api indonesia dan strategi pemanfaatan teknologi aplikasi KAI Access, beberapa generasi millennials kabupaten kebumen menyatakan telah mengetahui dan menggunakan aplikasi tersebut. Beberapa millennials berpendapat bahwa mereka percaya terhadap aplikasi KAI Access karena aplikasi tersebut adalah aplikasi resmi dari PT Kereta Api Indonesia. Sehingga timbul adanya niat atau intention generasi millennials untuk membeli tiket kereta api secara online melalui aplikasi KAI Access.

Menumbuhkan minat atau ketertarikan calon konsumen terhadap produk atau jasa yang perusahaan tawarkan adalah faktor yang sangat penting. Minat adalah sesuatu yang pribadi dan berhubungan dengan sikap. Individu yang berminat terhadap suatu objek akan memiliki dorongan untuk melakukan serangkaian perilaku untuk mendekati atau mendapatkan objek tersebut. Putu et al, (2016) Niat beli secara online dipengaruhi oleh berbagai faktor salah satunya adalah trust atau kepercayaan dari konsumen yang akan melakukan pembelian secara online. Pernyataan ini diperkuat oleh hasil penelitian terdahulu Setyo et al,. (2015) menyatakan bahwa variabel kepercayaan berpengaruh signifikan terhadap minat menggunakan produk. Berdasarkan teori TAM (Technology Acceptance Model) niat atau intention dipengaruhi oleh variabel perceived usefulness atau persepsi manfaat dan perceived ease of use atau kemudahan penggunaan.

Perceived Usefulness atau persepsi kemudahan adalah salah satu faktor yang mempengaruhi minat penggunaan aplikasi tiket kereta secara online, sehingga mempengaruhi kepercayaan untuk terbentuk dalam konsumen. Pernyataan ini diperkuat oleh hasil penelitian I Putu et al,. (2016) menyatakan bahwa perceived usefulness atau persepsi kemudahan berpengaruh positif dan signifikan terhadap minat penggunaan aplikasi. Menurut Jogiyanto (2008) mengemukakan definisi persepsi kegunaan yaitu sebagai sejauh mana individu yakin dengan menggunakan suatu teknologi akan meningkatkan kinerja pekerjaannya. Jika individu beranggapan dengan media informasi berguna maka dia akan menggunakannya. Sebaliknya jika individu beranggapan dengan media informasi kurang berguna maka dia tidak akan menggunakannya. Perceived Ease of Use atau persepsi kemudahan yang di dapat pengguna melalui aplikasi juga berpotensi mempengaruhi minat penggunaan aplikasi di dalam membeli tiket kereta secara online. Jogiyanto (2008) juga mengemukakan, definisi persepsi kemudahan sebagai sejauh mana individu yakin dengan menggunakan teknologi akan bebas dari usaha. Jika individu menganggap media informasi mudah digunakan maka dia akan menggunakannya. Sebaliknya jika individu menganggap media informasi tidak mudah digunakan maka dia tidak akan menggunakannya.

Dengan adanya layanan aplikasi mobile ticket melalui KAI Access yang dikeluarkan oleh PT Kereta Api Indonesia adalah salah satu strategi pemanfaatan teknologi atau cara untuk 
mendekatkan konsumen atau pengguna dengan jasa layanan kereta api. Selain mempermudah akses mendapatkan tiket kereta api secara online. Semua dilakukan untuk memberikan pelayanan terbaik kepada para pengguna jasa layanan kereta api. Akan tetapi tidak semua konsumen tertarik dan berniat untuk melakukan pembelian tiket kereta api secara online melalui aplikasi KAI Access. Hal tersebut berdampak pada masih terlihatnya antrian panjang penumpang di loket stasiun. Beberapa konsumen juga masih mengeluhkan sulitnya mendapatkan tiket kereta api, karena kelangkaan dan harus berebut dengan konsumen lain, dan masih banyak keluhan-keluhan mengenai pembelian tiket kereta api. Padahal dengan adanya aplikasi tiket KAI Access, konsumen dapat memesan tiket kereta api sesuai kebutuhan mereka jauh sebelum tanggal keberangkatan dan sesuai kebutuhan. Berdasarkan latar belakang masalah di atas, hal ini menjadi menarik untuk di teliti dan di ungkapkan agar menjadi bahan evaluasi dan pembelajaran di dalam mempertahankan bisnis jasa tranportasi meski banyaknya persaingan.

\section{Kajian Teori dan Telaah Literatur}

\section{Perceived usefulness}

Menurut Davis (1989) mengemukakan definisi persepsi kegunaan sebagai sejauh mana individu yakin dengan menggunakan suatu teknologi akan meningkatkan kinerja pekerjaannya. Jika individu beranggapan dengan media informasi berguna maka dia akan menggunakannya. Sebaliknya jika individu beranggapan dengan media informasi kurang berguna maka dia tidak akan menggunakannya. Menurut Davis (1989) perceived usefulness atau persepsi kegunaan dapat diukur dengan menggunakan indikator sebagai berikut: Useful (bermanfaat), Effectiveness (efektivitas), Improve job performance (meningkatkan kinerja), Make job easier (mempermudah pekerjaan), Work more quickly (dapat mempercepat pekerjaan).

$\mathbf{H}_{\mathbf{1}}$ : Perceived Usefulness berpengaruh positif terhadap Trust

\section{Perceived ease of use}

Menurut Davis (1989), perceived ease of use didefinisikan pada sejauh mana tingkat kepercayaan seseorang bahwa dengan menggunakan suatu sistem tertentu tidak memerlukan usaha yang keras atau kesulitan. Menurut Davis (1989), perceived ease of use di batasi pada: clear and understandable (jelas dan dapat dipahami), easy to use (mudah digunakan), easy to learn (mudah dipelajari), controllable (dapat di kontrol), flexible (fleksibel).

$\mathbf{H}_{2}$ : Perceived Ease of Use berpengaruh positif terhadap Trust.

\section{Trust}

Kepercayaan konsumen menurut Mowen (2002) adalah semua pengetahuan yang dimiliki oleh konsumen dan semua kesimpulan yang dibuat oleh konsumen tentang objek, atribut dan manfaatnya. Maksud dari objek disini adalah berupa produk, orang, perusahaan dan segala sesuatu dimana seseorang memiliki kepercayaan terhadap objek tersebut.

Menurut Sujana dan Suprapti (2016:604) aspek yang membangun kepercayaan seseorang dibatasi pada: Kepercayaan reputasi yang baik, Kepercayaan keandalan kinerja, Kepercayaan keamanan informasi, Kepercayaan keamanan bertransaksi.

$\mathbf{H}_{5}$ : Trust berpengaruh positif terhadap Intention to Buy 


\section{Intention to use}

Menurut Hartono (2007: 116), niat adalah suatu keinginan seseorang untuk melakukan perilaku tertentu. Seseorang akan melakukan sesuatu perilaku jika mempunyai keinginan atau niat untuk melakukannya.. Menurut Lim dan Ding (2012), batasan intention to use adalah: Intend to use (berniat untuk menggunakan), Increase usage (niat untuk meningkatkan penggunaan), Motivate other users (memotivasi ke pengguna lain).

$\mathbf{H}_{3}$ : Perceived Usefulness berpengaruh positif terhadap Intention to Buy

$\mathbf{H}_{4}$ : Perceived Ease of Use berpengaruh positif terhadap intention to Buy

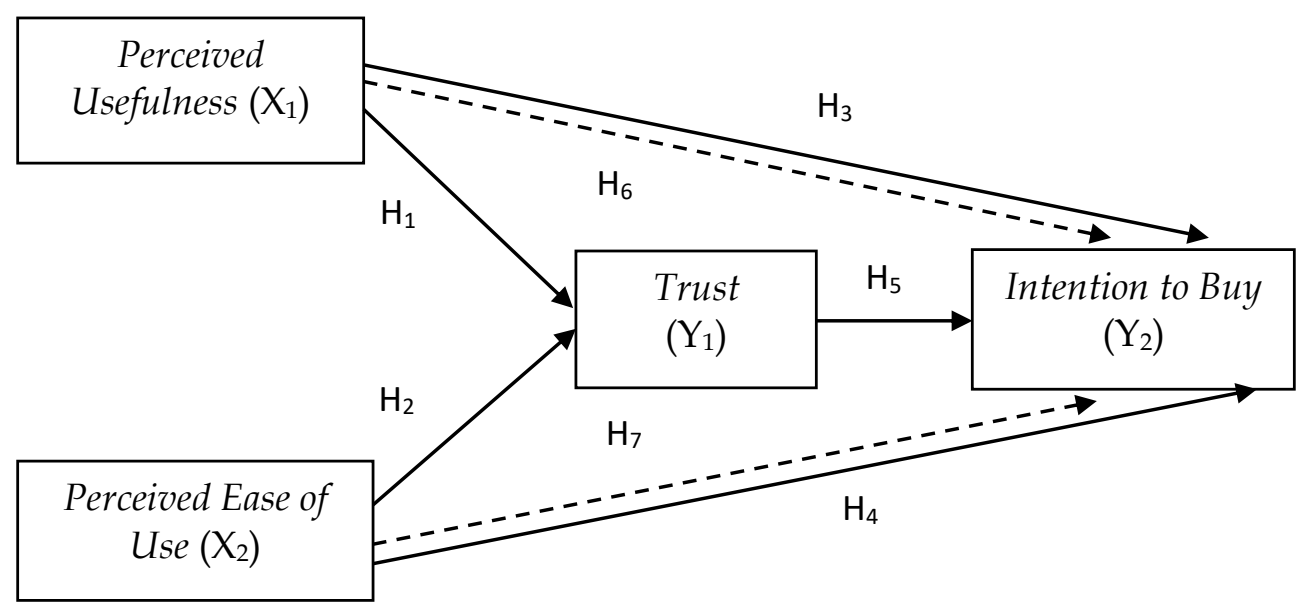

Gambar 1. Model penelitian

\section{Metode Penelitian}

Subjek dalam penelitian ini adalah masyarakat Kabupaten Kebumen yang merupakan generasi millennials pengguna jasa layanan transportasi kereta api yang berjumlah 100 responden. Populasi dalam penelitian ini adalah generasi millennials di Kabupaten Kebumen. Sedangkan sample dalam penelitian ini ditentukan dengan metode non probability sampling jenis purposive sampling yaitu generasi millennials yang menggunakan kereta api minimal 1 kali selama satu tahun terakhir dan menggunakan aplikasi KAI Access. Objek dalam penelitian ini adalah perceived usefulness, perceived ease of use, trust dan intention to buy. Teknik analisis yang digunakan dalam penelitian ini menggunakan analisis kuantitatif dengan butir pertanyaan kuisioner. Skala yang digunakan dalam penelitian ini menggunakan skala likert 5, dengan analisis data uji instrumen, uji asumsi klasik, uji hipotesis, uji sobel, uji korelasi dan analisis jalur.

\section{Hasil dan Pembahasan}

\section{Uji validitas}

Uji validitas digunakan untuk mengukur sah atau valid tidaknya suatu kuesioner yang digunakan terhadap semua instrumen variabel. 
Tabel 2. Hasil uji validitas

\begin{tabular}{cccccc}
\hline Variabel & Butir & Rhitung & Rtabel & Signifikansi & Keterangan \\
\hline & 1 & 0,836 & 0,1966 & 0,000 & Valid \\
Perceived & 2 & 0,894 & 0,1966 & 0,000 & Valid \\
Usefulness & 3 & 0,870 & 0,1966 & 0,000 & Valid \\
& 4 & 0,882 & 0,1966 & 0,000 & Valid \\
& 5 & 0,900 & 0,1966 & 0,000 & Valid \\
\hline
\end{tabular}

Sumber: Data diolah (2019)

Tabel 3. Hasil uji validitas

\begin{tabular}{crrrrl}
\hline Variabel & Butir & Rhitung & Rtabel & Signifikansi & Keterangan \\
\hline & 1 & 0,891 & 0,1966 & 0,000 & Valid \\
Perceived & 2 & 0,923 & 0,1966 & 0,000 & Valid \\
Ease of Use & 3 & 0,869 & 0,1966 & 0,000 & Valid \\
& 4 & 0,880 & 0,1966 & 0,000 & Valid \\
& 5 & 0,904 & 0,1966 & 0,000 & Valid \\
\hline
\end{tabular}

Sumber: Data diolah (2019)

Tabel 4. Hasil uji validitas

\begin{tabular}{cccccc}
\hline Variabel & Butir & \multicolumn{2}{l}{ Rhitung } & Rtabel & \multicolumn{2}{c}{ Signifikansi Keterangan } \\
\hline \multirow{4}{*}{ Trust } & 1 & 0,887 & 0,1966 & 0,000 & Valid \\
& 2 & 0,926 & 0,1966 & 0,000 & Valid \\
& 3 & 0,926 & 0,1966 & 0,000 & Valid \\
& 4 & 0,931 & 0,1966 & 0,000 & Valid \\
\hline
\end{tabular}

Sumber: Data diolah (2019)

Tabel 5. Hasil uji validitas

\begin{tabular}{cllccl}
\hline Variabel & Butir & rhitung & Rtabel & Signifikansi & Keterangan \\
\hline \multirow{2}{*}{ Intention } & 1 & 0,976 & 0,1966 & 0,000 & Valid \\
to Buy & 2 & 0,990 & 0,1966 & 0,000 & Valid \\
& 3 & 0,980 & 0,1966 & 0,000 & Valid \\
\hline
\end{tabular}

Sumber: Data diolah (2019)

\section{Uji reliabilitas}

Uji reliabilitas digunakan untuk mengukur sejauh mana suatu alat ukur dapat dipercaya atau diandalkan.

Tabel 6. Hasil uji reliabilitas

\begin{tabular}{lccc}
\hline \multicolumn{1}{c}{ Variabel } & Rkritis & $\begin{array}{c}\text { Cronbach's } \\
\text { Alpha }\end{array}$ & Keterangan \\
\hline Perceived Usfulness & 0,60 & 0,919 & Reliabel \\
Perceived Ease of Use & 0,60 & 0,937 & Reliabel \\
Trust & 0,60 & 0,935 & Reliabel \\
Intention to Buy & 0,60 & 0,980 & Reliabel \\
\hline
\end{tabular}

Sumber: Data diolah (2019) 
Berdasarkan hasil pengujian reliabilitas pada tabel di atas, menunjukkan bahwa instrumeninstrumen yang digunakan dalam penelitian ini memiliki nilai cronbach's alpha $>\mathrm{r}_{\text {kritis }}(0,60)$. Berdasarkan hasil tersebut, dapat disimpulkan bahwa semua instrumen dalam penelitian dinyatakan reliabel.

\section{Uji asumsi klasik}

Pengujian asumsi klasik digunakan untuk menguji kelayakan atas model regresi yang digunakan dalam penelitian dengan maksud untuk memastikan bahwa di dalam model regresi yang digunakan tidak terdapat multikolinearitas, heteroskedastisitas serta memastikan bahwa data penelitian berdistribusi secara normal.

\section{Uji normalitas}

Berdasarkan hasil uji normalitas terlihat bahwa titik-titik menyebar di sekitar garis diagonal dan mengikuti arah garis diagonal. Hasil tersebut menunjukkan nilai residual terstandarisasi terdistribusi normal, sehingga dapat disimpulkan bahwa model regresi substruktural 1 dan substruktural 2 dalam penelitian ini telah memenuhi asumsi normalitas.

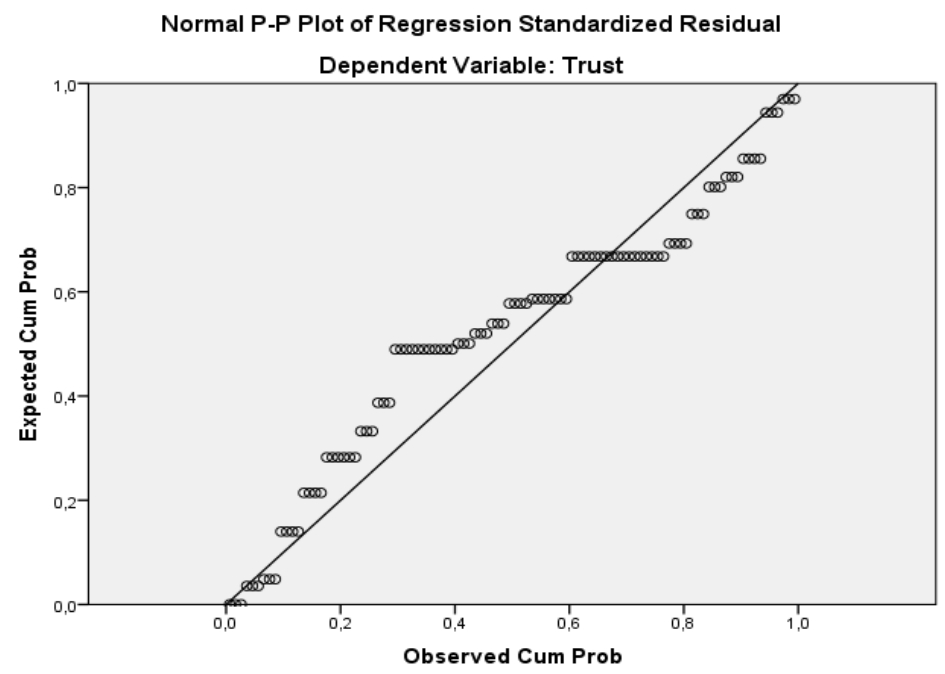

Gambar 2. Hasil uji normalitas substruktural 1

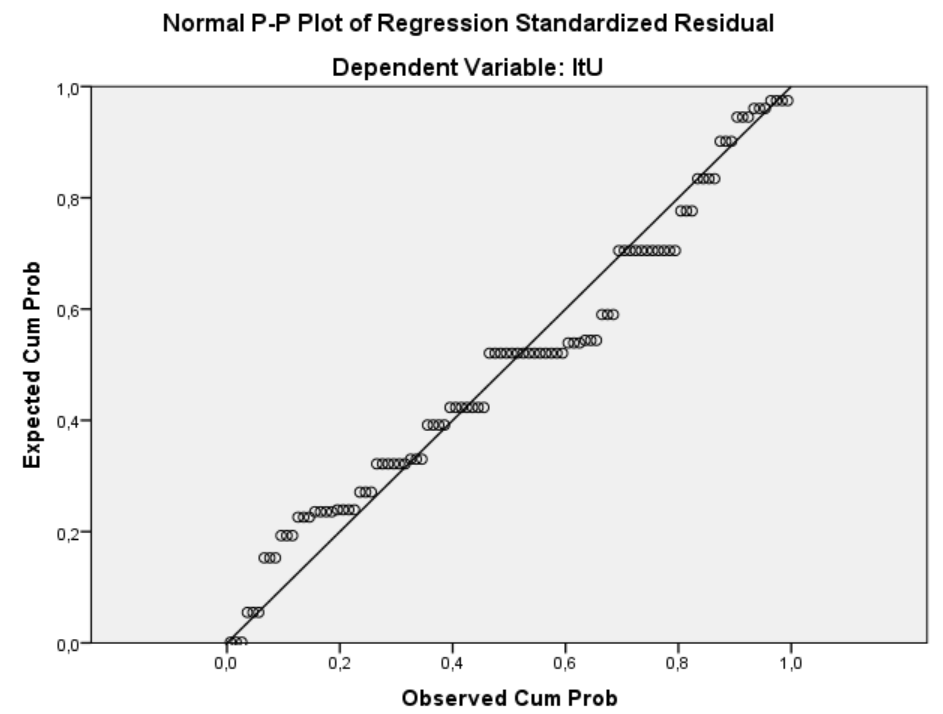

Gambar 3. Hasil uji normalitas substruktural 2 


\section{Uji multikolinearitas}

Berdasarkan hasil pengujian multikolinearitas pada tabel IV-13 diatas, dapat dilihat pada kolom collinearity statistics yang menunjukkan nilai tolerance dari variabel bebas perceived usefulness, perceived ease of use dan trust lebih besar dari 0,10 dan nilai VIF tidak lebih besar dari 10, sehingga dapat disimpulkan bahwa model regresi substruktural 2 dalam penelitian ini tidak terjadi multikolinearitas.

\begin{tabular}{|c|c|c|}
\hline \multirow{2}{*}{ Model } & \multicolumn{2}{|c|}{ Collinearity Statistics } \\
\hline & Tolerance & VIF \\
\hline (Constant) & & \\
\hline Perceived Usefulness & 0,381 & 2,623 \\
\hline Perceived Ease of Use & 0,381 & 2,623 \\
\hline \multicolumn{3}{|c|}{ a. Dependent Variable: Trust } \\
\hline \multicolumn{3}{|c|}{ Sumber: Data diolah (2019) } \\
\hline \multicolumn{3}{|c|}{ Tabel 8. Hasil uji multikolinearitas substruktural 2} \\
\hline \multirow{2}{*}{ Model } & \multicolumn{2}{|c|}{ Collinearity Statistics } \\
\hline & Tolerance & VIF \\
\hline \multicolumn{3}{|l|}{$1 \quad$ (Constant) } \\
\hline Perceived Usefulness & 0,337 & 2,970 \\
\hline Perceived Ease of Use & 0,295 & 3,392 \\
\hline Trust & 0,341 & 2,929 \\
\hline
\end{tabular}

\section{Uji heterokedastisitas}

Berdasarkan hasil uji heteroskedastisitas pada gambar, menunjukkan bahwa plot dalam scatterplot menyebar secara acak di atas maupun di bawah angka nol pada sumbu regression studentized residual, sehingga dapat disimpulkan bahwa model regresi substruktural 2 dalam penelitian ini tidak terjadi gejala heteroskedastisitas.

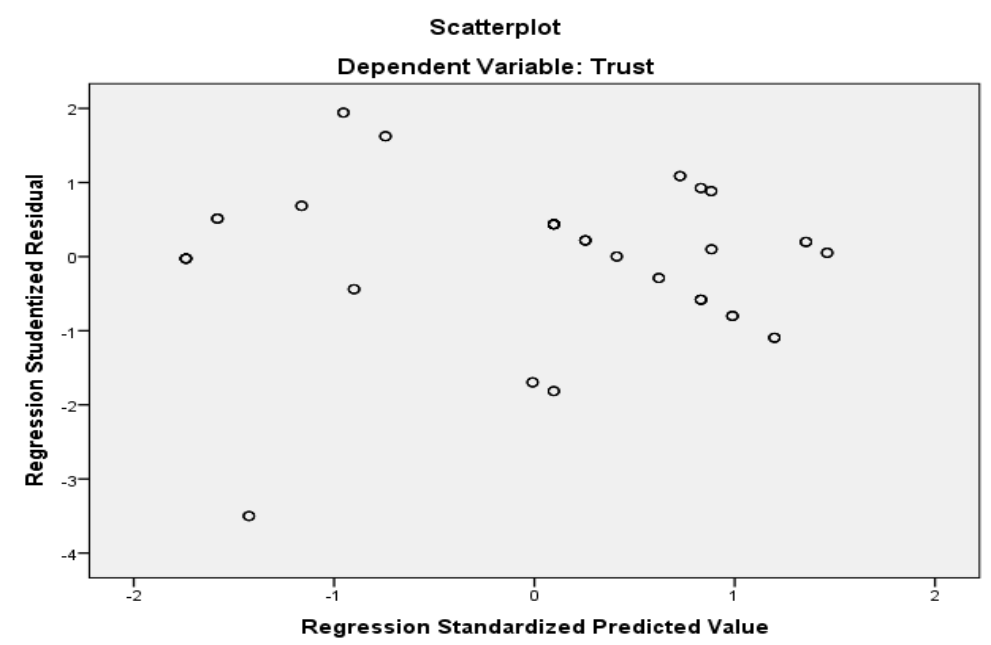

Gambar 4. Hasil uji heteroskedastisitas substruktural 1 


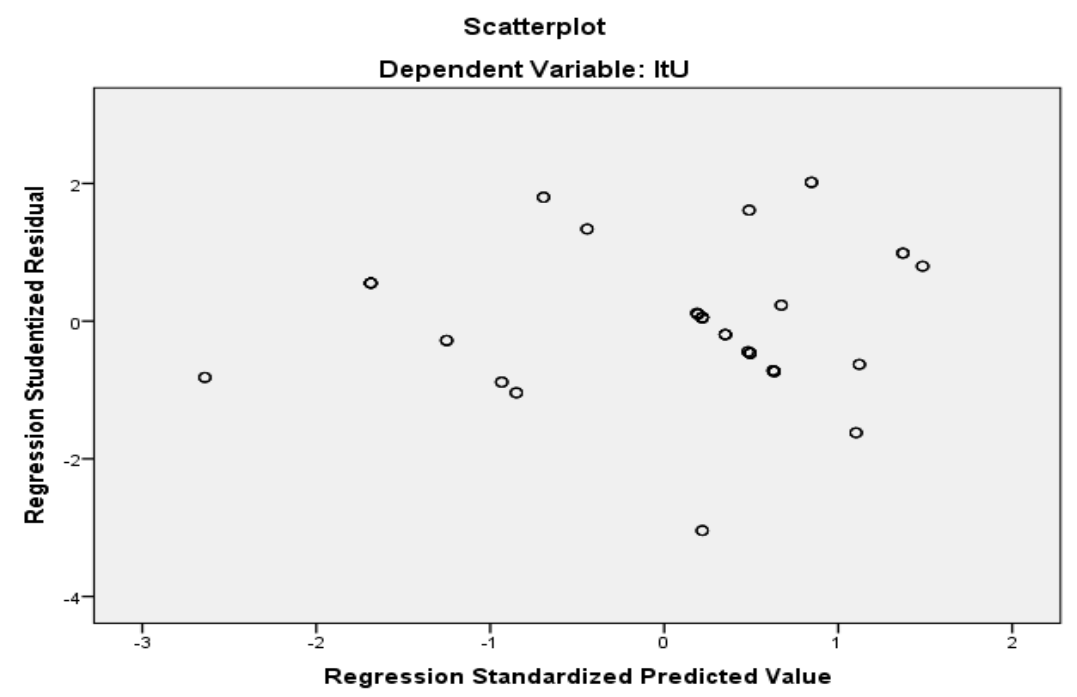

Gambar 5. Hasil uji heteroskedastisitas substruktural 2

\section{Uji hipotesis}

Kriteria pengujian uji $t$ dalam penelitian ini adalah jika $t_{\text {hitung }}<t_{\text {tabel }}$ dan signifikansi $>0,05$ maka tidak terdapat pengaruh yang signifikan atau hipotesis (Ha) ditolak. Jika $t_{\text {hitung }}>t_{\text {tabel }}$ dan signifikansi < 0,05 maka terdapat pengaruh yang signifikan atau hipotesis (Ha) diterima. Berikut perhitungan nilai $t_{\text {tabel }}$ dalam penelitian ini:

$$
\begin{aligned}
& \text { Degree of freedom }(d f)=a,(n-k) \\
& =0,05,(100-2) \\
& =0,05,(98) \\
& =1,98447 / 1,985
\end{aligned}
$$

Tabel 9. Koefisien jalur

\begin{tabular}{cccccc}
\hline Hipotesis & $\begin{array}{c}\text { Hubungan } \\
\text { Variabel }\end{array}$ & Thitung & Ttabel & Signifikansi & Keterangan \\
\hline $\mathrm{H}_{1}$ & PU Trust & 3,582 & 1,985 & 0,001 & Diterima \\
$\mathrm{H}_{2}$ & PEoU Trust & 5,334 & 1,985 & 0,000 & Diterima \\
$\mathrm{H}_{3}$ & PU ItB & 3,829 & 1,985 & 0,000 & Diterima \\
$\mathrm{H}_{4}$ & PEoU ItB & 0,188 & 1,985 & 0,852 & Ditolak \\
$\mathrm{H}_{5}$ & Trust ItB & 7,507 & 1,985 & 0,000 & Diterima \\
\hline
\end{tabular}

Sumber: Data primer diolah, Tahun (2019)

\section{Koefisien determinasi}

Koefisien determinasi dalam penelitian ini digunakan untuk mengukur seberapa jauh kemampuan model dalam menerangkan variasi variabel dependen. Besarnya pengaruh atau kontribusi variabel independen dengan variabel dependen dapat dilihat dari nilai Adjusted $R^{2}$. Berikut hasil uji koefisien determinasi dalam penelitian ini: 
Tabel 10. Hasil uji koefisien determinasi substruktural 1 Model summaryb

\begin{tabular}{rrrrr}
\hline Model & $\mathrm{R}$ & R Square & $\begin{array}{c}\text { Adjusted } \mathrm{R} \\
\text { Square }\end{array}$ & Std. Error of the Estimate \\
\hline 1 &, $812^{\mathrm{a}}$ &, 659 &, 652 & 1,340 \\
\hline
\end{tabular}

a. Predictors: (Constant), Perceived Ease of Use , Perceived Usefulness

b. Dependent Variable: Trust

Berdasarkan hasil uji koefisien determinasi pada tabel di atas, menunjukkan nilai Adjusted $R^{2}$ substruktural 1 sebesar 0,652. Artinya sebesar 65,2\% variabel trust dapat dijelaskan oleh variabel perceived usefulness dan variabel perceived ease of use. Sebesar 34,8\% (100\% - 65,2\%) dapat dijelaskan oleh variabel lain yang tidak ada dalam model penelitian ini.

Tabel 11. Hasil uji koefisien determinasi substruktural 2 Model summaryb

\begin{tabular}{lrrrr}
\hline Model & $\mathrm{R}$ & R Square & $\begin{array}{c}\text { Adjusted } \mathrm{R} \\
\text { Square }\end{array}$ & Std. Error of the Estimate \\
\hline 1 &, $885^{\mathrm{a}}$ &, 783 &, 776 &, 976 \\
\hline
\end{tabular}

a. Predictors: (Constant), Trust, Perceived Usefulness, Perceived Ease of Use

b. Dependent Variable: Intention to Buy

Berdasarkan hasil uji koefisien determinasi pada tabel di atas, menunjukkan nilai Adjusted $R^{2}$ substruktural 2 sebesar 0,776. Artinya sebesar 77,6\% variabel intention to use dapat dijelaskan oleh variabel perceived usefulness, variabel perceived ease of use dan variable trust. Sebesar $22,4 \%(100 \%-77,6 \%)$ dapat dijelaskan oleh variabel lain yang tidak ada dalam model penelitian ini.

\section{Uji sobel}

Tabel 12. Hasil uji sobel

\begin{tabular}{ccc}
\hline Test Statistic & Standar Error & P Value \\
\hline 3,23098747 & 0,04981449 & 0,00123363 \\
\hline
\end{tabular}

Berdasarkan Tabel IV-19, menunjukkan bahwa hasil test statistic $>_{\mathrm{t}}$ tabel yaitu 3,23098747 $>1,985$ dan $p$-value <a yaitu 0,00123363 < 0,05. Maka dapat dikatakan bahwa trust dapat memediasi perceived usefulness dan intention to buy.

Tabel 13. Hasil uji sobel

\begin{tabular}{ccc}
\hline Test Statistic & Standar Error & P Value \\
\hline 4,32907573 & 0,04961452 & 0,00001497 \\
\hline
\end{tabular}

Berdasarkan Tabel IV-19, menunjukkan bahwa hasil test statistic $>\mathrm{t}$ tabel yaitu 4,32907573 $>1,985$ dan $p$-value <a yaitu 0,00001497 < 0,05. Maka dapat dikatakan bahwa trust dapat memediasi perceived ease of use dan intention to buy. 
Analisis korelasi

Tabel 14. Hasil uji analisis korelasi Correlations

\begin{tabular}{llrr}
\hline & & $\begin{array}{c}\text { Perceived } \\
\text { Usefulness }\end{array}$ & $\begin{array}{r}\text { Perceived Ease } \\
\text { of Use }\end{array}$ \\
\hline Perceived & Pearson Correlation & 1 &, $787^{* *}$ \\
Usefulness & Sig. (2-tailed) & 100 &, 000 \\
& $\mathrm{~N}$ &, $787^{* *}$ & 100 \\
\hline Perceived & Pearson Correlation &, 000 & 1 \\
Ease of Use & Sig. (2-tailed) & 100 & 100 \\
& $\mathrm{~N}$ &
\end{tabular}

\section{Analisis jalur}

Tabel 14. Hasil uji koefisien jalur substruktural 1 model summary

\begin{tabular}{lrrrr}
\hline Model & $\mathrm{R}$ & $\mathrm{R}$ Square & $\begin{array}{c}\text { Adjusted R } \\
\text { Square }\end{array}$ & Std. Error of the Estimate \\
\hline 1 &, $812^{\mathrm{a}}$ &, 659 &, 652 & 1,340 \\
\hline $\begin{array}{l}\text { a. Predictors: (Constant), Perceived Ease of Use , Perceived Usefulness } \\
\text { b. Dependent Variable: Trust }\end{array}$
\end{tabular}

\section{Coefficients ${ }^{\mathrm{a}}$}

\begin{tabular}{llrrrrr}
\hline & & \multicolumn{2}{c}{ Unstandardized } & \multicolumn{2}{c}{$\begin{array}{c}\text { Standardized } \\
\text { Model }\end{array}$} & \multicolumn{2}{c}{ Coefficients } & \multicolumn{2}{c}{ Coefficients } & \multirow{2}{*}{ T } & \multirow{2}{*}{ Sig. } \\
\cline { 2 - 4 } & \multicolumn{1}{c}{ B } & Std. Error & Beta & & \\
\hline 1 & (Constant) & 1,269 &, 772 & & 1,644 &, 103 \\
& Perceived Usefulness &, 290 &, 081 &, 344 & 3,582 &, 001 \\
& Perceived Ease of Use &, 387 &, 073 &, 512 & 5,334 &, 000 \\
\hline
\end{tabular}

a. Dependent Variable: Trust

Tabel 15. Hasil uji koefisien jalur substruktural 2 Model summary ${ }^{b}$

\begin{tabular}{|c|c|c|c|c|}
\hline Model & $\mathrm{R}$ & R Square & $\begin{array}{c}\text { Adjusted R } \\
\text { Square }\end{array}$ & Std. Error of the Estimate \\
\hline 1 & $885^{\mathrm{a}}$ & ,783 & ,776 & ,976 \\
\hline
\end{tabular}

\section{Coefficients ${ }^{a}$}

\begin{tabular}{|c|c|c|c|c|c|c|}
\hline & \multirow[t]{2}{*}{ Model } & \multicolumn{2}{|c|}{$\begin{array}{l}\text { Unstandardized } \\
\text { Coefficients }\end{array}$} & \multirow{2}{*}{$\begin{array}{c}\begin{array}{c}\text { Standardized } \\
\text { Coefficients }\end{array} \\
\text { Beta }\end{array}$} & \multirow[t]{2}{*}{$\mathrm{T}$} & \multirow[t]{2}{*}{ Sig. } \\
\hline & & $\mathrm{B}$ & Std. Error & & & \\
\hline \multirow[t]{4}{*}{1} & (Constant) & $-1,477$ &, 570 & & $-2,593$ & ,011 \\
\hline & Perceived Usefulness & ,240 & ,063 & ,314 & 3,829 & ,000 \\
\hline & Perceived Ease of Use & ,011 &, 060 & ,016 & 188 & ,852 \\
\hline & Trust &, 555 & ,074 & 611 & 7,507 & ,000 \\
\hline
\end{tabular}

a. Dependent Variable: Intention to Buy 
Berdasarkan analisis jalur dapat dijelaskan bahwa :

a. Penelitian ini terdapat dua variabel independen yaitu perceived usefulness dan perceived ease of use, dimana keduanya memiliki korelasi yang sangat kuat yaitu sebesar 0,787 atau $78,7 \%$.

b. Pengaruh variabel perceived usefulness terhadap variabel trust yaitu sebesar 0,344 atau $34,4 \%$.

c. Pengaruh variabel perceived ease of use terhadap variable trust yaitu sebesar 0,512 atau $51,2 \%$.

d. Besarnya nilai $€_{1}$ yaitu 0,583 atau $58,3 \%$ berarti bahwa jumlah variance variabel trust yang tidak dapat dijelaskan oleh variabel perceived usefulness dan variabel perceived ease of use diabaikan atau sama dengan nol (0).

e. Pengaruh variable perceived usefulness terhadap variable intention to buy secara langsung yaitu sebesar 0,314 atau 31,4\%.

f. Pengaruh variabel perceived ease of use terhadap variable intention to buy secara langsung yaitu sebesar 0,016 atau 1,6\%.

g. Pengaruh variabel trust terhadap variable intention to buy secara langsung yaitu sebesar 0,611 atau $61,1 \%$.

h. Besarnya nilai $€_{2}$ yaitu 0,465 atau $45,0 \%$ berarti bahwa jumlah variance variabel intention to buy yang tidak dapat dijelaskan oleh variabel perceived usefulness, variabel perceived ease of use dan variabel trust diabaikan atau sama dengan nol (0).

\section{Penutup dan Saran}

Berdasarkan hasil pembahasan analisis data melalui pembuktian terhadap hipotesis dari permasalahan yang diangkat mengenai faktor-faktor yang mempengaruhi intention to buy aplikasi KAI Access pada generasi millennial pengguna jasa layanan transportasi Kereta Api Indonesia (KAI) di Kabupaten Kebumen, maka dapat diperoleh kesimpulan sebagai berikut:

a. Perceived usefulness berpengaruh signifikan terhadap trust pada generasi millennials pengguna jasa layanan transportasi Kereta Api Indonesia (KAI) di Kabupaten Kebumen. Hal ini menunjukkan bahwa semakin tinggi perceived usefulness yang akan diperoleh maka akan membentuk trust atau kepercayaan terhadap penggunaan aplikasi KAI Access dalam pembelian tiket kereta api secara online.

b. Perceived ease of use berpengaruh signifikan terhadap trust pada generasi millennials pengguna jasa layanan transportasi Kereta Api Indonesia (KAI) di Kabupaten Kebumen. Hal ini menunjukkan semakin tinggi perceived ease of use maka akan mampu meningkatkan trust atau kepercayaan terhadap penggunaan aplikasi KAI Access dalam pembelian tiket kereta api secara online.

c. Perceived usefulness berpengaruh signifikan terhadap intention to use aplikasi KAI Access pada generasi millennials pengguna jasa layanan transportasi Kereta Api Indonesia (KAI) di Kabupaten Kebumen. Hal ini menunjukkan bahwa perceived usefulness mampu untuk meningkatkan intention to buy sebagai media atau aplikasi yang bermanfaat utnuk para pengguna kereta api, terutama dalam pembelian dan informasi mengenai tiket kereta api.

d. Perceived ease of use tidak berpengaruh signifikan terhadap intention to buy aplikasi KAI Access pada generasi millennials pengguna jasa layanan transportasi Kereta Api 
Indonesia (KAI) di Kabupaten Kebumen. Hal ini menunjukkan bahwa perceived ease of use tidak mampu untuk meningkatkan intention to buy aplikasi KAI Access karena sebagian millenials berpendapat bahwa fitur dalam aplikasi KAI Access terkadang sulit digunakan atau terjadi error dan bermasalah. Contohnya seperti halaman browser atau web yang loading terlalu lama, akun pengguna keluar secara otomatis, kesulitan mencari tiket yang di butuhkan, kesulitan mengedit dan menyesuaikan data pengguna.

e. Trust berpengaruh signifikan terhadap intention to buy aplikasi KAI Access pada generasi millennials pengguna jasa layanan transportasi Kereta Api Indonesia (KAI) di Kabupaten Kebumen. Hal ini menunjukkan bahwa semakin tinggi tingkat trust maka akan semakin tinggi juga intention to use aplikasi KAI Access sebagai aplikasi pembelian tiket tiket kereta api secara online.

f. Perceived Usefulness berpengaruh signifikan terhadap intention to buy online ticket KAI Access melalui trust. Hal ini menunjukkan bahwa trust dapat dihasilkan dari adanya perceived usefulness dalam suatu teknologi sehingga menimbulkan niat untuk membeli tiket online dengan menggunakan aplikasi KAI Access.

g. Perceived Ease of Use berpengaruh signifikan terhadap intention to buy online ticket KAI Access melalui trust. Hal ini menunjukkan bahwa trust dapat dihasilkan dari adanya perceived ease of use dalam penggunaan suatu teknologi sehingga menimbulkan niat untuk membeli tiket online dengan menggunakan aplikasi KAI Access.

\section{Saran}

Berdasarakan penelitian terhadap satu hipotesis di tolak yaitu perceived ease use tidak berpengaruh terhadap intention to buy. Berdasarkan penelitian beberapa responden berpendapat bahwa terkadang aplikasi KAI Access sering mengalami gangguan sever, oleh sebab itu diharapkan PT Kereta Api Indonesia dapat lebih meningkatkan layanan dengan memperbaiki kinerja dari aplikasi KAI Access.

\section{Referensi}

Aditya, R., \& Wardhana, A. (2016). Pengaruh perceived usefulness dan perceived ease of use terhadap behavioral intention dengan pendekatan Technology Acceptance Model (TAM) pada pengguna Instant Messaging LINE di Indonesia. Jurnal Siasat Bisnis, 20(1), 24-32.

Almahamid, S., McAdams, A. C., Kalaldeh, T. M. A., \& Mo'taz, A. A. (2010). The relationship between perceived usefulness, perceived ease of use, perceived information quality, and intention to use e-government. Journal of Theoretical $\mathcal{E}$ Applied Information Technology, 11.

Ardhanari, M. (2012). Customer satisfaction pengaruhnya terhadap brand preference dan repurchase intention private brand. Jurnal Riset Ekonomi dan Bisnis, 8(2), 58-69.

Badan Pusat Statistik Indonesia. 2019. Diambil dari http://www.bps.go.id. Diakses di Kebumen pada tanggal 15 November 2019 
Bangkara, R. P., \& Mimba, N. P. S. H. (2016). Pengaruh Perceived Usefulness dan Perceived Ease of Use pada Minat Penggunaan Internet Banking dengan Attitude Toward Using sebagai Variabel Intervening. E-Jurnal Akuntansi, 16(3), 2408-2434.

Budiantara, M., Gunawan, H., \& Utami, E. S. (2019). Perceived Usefulness, Perceived Ease of Use, Trust in Online Store, Perceived Risk sebagai Pemicu Niat Beli Online pada Produk UMKM "Made in Indonesia" Melalui Penggunaan E-Commerce Marketplace. Jurnal Riset Akuntansi Mercu Buana, 5(1), 19-27.

Choi, E. J., \& Kim, S. H. (2013). The study of the impact of perceived quality and value of social enterprises on customer satisfaction and re-purchase intention. International Journal of Smart Home, 7(1), 239-252.

Davis, F. D. (1989). Perceived usefulness, perceived ease of use, and user acceptance of information technology. MIS quarterly, 319-340.

Davis, F. D., Bagozzi, R. P., \& Warshaw, P. R. (1989). User acceptance of computer technology: a comparison of two theoretical models. Management science, 35(8), 9821003.

Eriksson, K., Kerem, K., \& Nilsson, D. (2005). Customer acceptance of internet banking in Estonia. International journal of bank marketing, 23(3), 200-216.

Fahmi, I. (2016). Perilaku Konsumen : Teori dan Aplikasi. Bandung: Alfabeta

Farmani, M., Kimiaee, A., \& Fatollahzadeh, F. (2012). Investigation of Relationship between ease of use, innovation tendency, perceived usefulness and intention to use technology: An empirical study. Indian Journal of Science and Technology, 5(11), 3678-3682.

Firdayanti, R. (2012). Persepsi risiko melakukan e-Commerce dengan kepercayaan konsumen dalam membeli produk fashion online. Journal of Social and Industrial Psychology, 1(1), 2252-6838

Ghozali, I. (2006). Aplikasi Analisis Multivariate dengan Program SPSS. Semarang: Badan Penerbit Universitas Diponegoro.

Hadi, S. (2004). Metodologi Research 2. Yogyakarta: Andi Offset.

Hartono, J. (2007). Sistem informasi keperilakuan. Yogyakarta: Andi Offset.

Haryanto, H. P. (2011). Niat Adopsi E-Commerce Wirausawan Mahasiswa (Studi pada Mahasiswa UNS). Jurnal Ekonomi dan Kewirausahaan, 11(1), 32-37.

Kotler, P., \& Keller, K. L. (2009). Manajemen Pemasaran. Edisi Ketiga Belas. Jilid 1. Jakarta: Erlangga

Kotler, P., \& Keller, K. L. (2012). Manajemen Pemasaran. Edisi Ketiga Belas. Jilid 2 Terjemahan. Jakarta : Erlangga

Kuncoro, M. (2009). Metode Riset untuk Bisnis dan Ekonomi. Edisi ke-3. Jakarta: Erlangga.

McKnight, D. H., Choudhury, V., \& Kacmar, C. (2002). The impact of initial consumer trust on intentions to transact with a web site: a trust building model. The journal of strategic information systems, 11(3-4), 297-323. 
Moorman, C., Deshpande, R., \& Zaltman, G. (1993). Factors affecting trust in market research relationships. Journal of marketing, 57(1), 81-101.

Mowen, J. C., \& Minor, M. (2002).Perilaku Konsumen. Jakarta : Erlangga

Nazir, M. (2003). Metode Penelitian. Cetakan Kelima. Jakarta : Ghalia Indonesia.

Purwandari, S. (2016). ANTESEDEN NIAT ADOPSI E-COMMERCE (Studi Kasus Pada Mahasiswa Politeknik Indonusa Surakarta). Jurnal Sainstech, 1(6), 59-72.

Putra, I. P. A. P. A., Sukaatmadja, I. P. G., \& Giantari, I. G. K. (2016). Pengaruh Persepsi Kemudahan Penggunaan, Persepsi Risiko, Terhadap Kepercayaan dan Niat Beli Eticket pada Situs Traveloka. E-Jurnal Ekonomi Dan Bisnis Universitas Udayana.

Rizan, M., Haro, A., \& Rahmadhina, B. (2019). Pengaruh Perceived Ease of Use dan Service Quality Terhadap Customer Satisfaction dengan Trust sebagai Intervening (Studi Kasus pada Pengguna Grab di Wilayah Jakarta). JRMSI-Jurnal Riset Manajemen Sains Indonesia, 10(2), 337-355.

Salamah, I., Aryanti, A., Lindawati, L., \& Asriyadi, A. (2017). Model Penerimaan Teknologi E-Commerce UMKM Kain Tenun Songket Kota Palembang. In Annual Research Seminar (ARS), 3(1), 109-114.

Saputro, B. D., \& Sukirno, S. (2013). Pengaruh Persepsi Kemudahan Penggunaan, Kepercayaan, Kecemasan Berkomputer Dan Kualitas Layanan Terhadap Minat Menggunakan Internet Banking. Nominal, Barometer Riset Akuntansi dan Manajemen, 2(1), 36-63.

Sarwono, J. (2007). Analisis Jalur untuk Riset Bisnis dengan SPSS. Yogyakarta: CV. Andi Offset

Schiffman, L. G., \& Kanuk, L. L. (2008). Costumer Behavior. Edisi 7. Pearson Education Australia.

Sekaran, U. (2011). Metode Penelitian untuk Bisnis. Edisi ke-4. Jakarta: Salemba Empat.

Semuel, H., \& Wijaya, N. (2009). Service quality, perceive value, satisfaction, trust, dan loyalty pada PT. Kereta Api Indonesia menurut penilaian pelanggan Surabaya. Jurnal Manajemen Pemasaran, 4(1), 23-37.

Simamora, B. (2004). Panduan Riset Perilaku Konsumen. Jakarta: PT. Gramedia Pustaka Utama.

Sopiah, \& Sangadji, E. M. (2013). Perilaku Konsumen Pendekatan Praktis Disertai Himpunan Jurnal Penelitian. Yogyakarta: Andi

Sudarsono, H. (2003). Bank dan Lembaga Keuangan Syariah (Deskripsi dan Ilstrasi). Yogyakarta: Ekonomi.

Sugiyono. (2006). Metode Penelitian Bisnis. Bandung: ALFABETA

Sugiyono. (2009). Metode Penelitian Bisnis. Bandung: ALFABETA

Sugiyono. (2010). Metode Penelitian Kuantitatif Kualitatif dan RED. Bandung: ALFABETA 
Sujana, K. C., \& Suprapti, N. W. S. (2016). Peran kepercayaan dalam memediasi pengaruh kualitas situs terhadap niat konsumen untuk berbelanja di situs zalora. E-Jurnal Manajemen, 5(1), 595-622

Suliyanto. (2011). Ekonometrika Terapan: Teori dan Aplikasi Dengan SPSS. Edisi 1. Yogyakarta: ANDI Yogyakarta.

Sumarsono, S. (2004). Metode Riset Sumber Daya Manusia. Yogyakarta: Graha Ilmu

Sunaryo. (2004). Psikologi Untuk Keperawatan. Jakarta: EGC

Suryani , T. (2013). Perilaku Konsumen di Era Internet. Yogyakarta : Graha Ilmu.

Suwondo, A., Sarana, S., \& Marjan, F. I. (2017). Analisis Pengaruh E-Kepuasan Pelanggan Terhadap E-Loyalitas Pelanggan KAI Access Berdasarkan E-Servqual Pada PT Kereta Api Indonesia (Persero) Daop IV Semarang. In Prosiding Sentrinov (Seminar Nasional Terapan Riset Inovatif) (Vol. 3, No. 1, pp. EB338-EB360).

Suwondo, A., Sarana, S., \& Marjan, F. I. (2017). Analisis Pengaruh E-Kepuasan Pelanggan Terhadap E-Loyalitas Pelanggan KAI Access Berdasarkan E-Servqual Pada PT Kereta Api Indonesia (Persero) Daop IV Semarang. In Prosiding Sentrinov (Seminar Nasional Terapan Riset Inovatif) (Vol. 3, No. 1, pp. EB338-EB360).

Tjiptono, F. (2007). Strategi Pemasaran.Edisi Kedua.Yogyakarta : Andi Offset

Uthruva, Tirta., Nuning, S., \& Arip, W. (2016). Faktor-Faktor yang Berpengaruh terhadap Niat Penggunaan E-Commerce Bagi Pelaku UMKM Agribisnis di Kabupaten Sukoharjo. AGRISTA, 4(1), 91-102.

Wasiun, R., Nugraha, H. S., \& Prabawani, B. (2015). Pengaruh Pelayanan Sistem Online, Tarif, Dan Publikasi Terhadap Keputusan Pembelian Secara Online Tiket Kereta Api Relasi Semarang - Jakarta (Studi Kasus Pada PT. Kereta Api Indonesia DAOP IV Semarang Tawang). Jurnal Ilmu Administrasi Bisnis S1 Undip, 4(2), 86-96.

Wibowo, A. (2008). Kajian tentang Perilaku Pengguna Sistem Informasi dengan Pendekatan Technology Acceptance Model (TAM). Universitas Budi Luhur, Jakarta.

Wibowo, S. F., Rosmauli, D., \& Suhud, U. (2015). Pengaruh Persepsi Manfaat, Persepsi Kemudahan, Fitur Layanan, Dan Kepercayaan Terhadap Minat Menggunakan EMoney Card (Studi Pada Pengguna Jasa Commuterline Di Jakarta). JRMSI-Jurnal Riset Manajemen Sains Indonesia, 6(1), 440-456.

Wong, D. (2017). Pengaruh Ability, Benevolence Dan Integrity Terhadap Trust, Serta Implikasinya Terhadap Partisipasi Pelanggan E-Commerce: Studi Kasus Pada Pelanggan E-Commerce Di Ubm. Jurnal Riset Manajemen Dan Bisnis (JRMB) Fakultas Ekonomi UNIAT, 2(2), 155-168. 